\title{
Control of Conyza spp. with sequential application of glufosinate in soybean pre-sowing
}

\author{
Alfredo Junior Paiola Albrecht ${ }^{1}$ Leandro Paiola Albrecht ${ }^{1}$ André Felipe Moreira Silva ${ }^{2 *}$ (B) \\ Romulo Augusto Ramos $^{3}$ Natália Buttini Corrêa ${ }^{1}$ Matheus Greguer de Carvalho ${ }^{1}$ \\ Juliano Bortoluzzi Lorenzetti ${ }^{1}$ Maikon Tiago Yamada Danilussi ${ }^{1}$
}

${ }^{1}$ Universidade Federal do Paraná (UFPR), Palotina, PR, Brasil.

${ }^{2}$ Crop Science Pequisa e Consultoria Agronômica, 85950-000, Palotina, PR, Brasil. E-mail: afmoreirasilva@hotmail.com. "Corresponding author. ${ }^{3}$ Basf S.A., Santo Antônio de Posse, SP, Brasil.

ABSTRACT: Conyza spp. is among the main weeds reported worldwide. Due to its aggressiveness, such as high seed production and dispersion, and the growing reports of biotypes resistant to glyphosate, paraquat, and other herbicides, different control practices are required. Thus, this study aimed to evaluate the efficacy of herbicides with sequential application of glufosinate in soybean pre-sowing for control of Conyza spp. with indicative of resistant to paraquat. The study was carried out in the field, at Assis Chateaubriand and Palotina, state of Paraná, Brazil, in the 2018/19 season. The experiments were conducted in a randomized block design with four replications. The treatments consisted in application of glyphosate, 2,4-D, saflufenacil, glufosinate, saflufenacil/imazethapyr, diclosulam, paraquat/diuron, paraquat and imazethapyr/flumioxazin, at different combinations, in soybean pre-sowing. Control of Conyza spp., crop injury to soybean plants and variables related to agronomic performance (plant height and yield) were evaluated. All treatments were selective for soybean, which showed stronger crop injury in the presence of diclosulam herbicide, but this did not compromise soybean agronomic performance. In general, control levels were high for the treatments used. Except for paraquat treatments, in the area with the highest frequency of Conyza spp. with indicative of resistant to paraquat, and imazethapyr/flumioxazin treatment in both areas. These control results emphasized the importance of glufosinate in this management system and showed promising results for saflufenacil/imazethapyr.

Key words: glyphosate resistance, paraquat resistance, glutamine synthetase inhibitors, Glycine max L. Merr.

Controle de Conyza spp. com aplicação sequencial de glufosinate em pré-semeadura da soja

RESUMO: A planta daninha Conyza spp. está entre as principais encontradas em todo o mundo. Devido a sua agressividade, como elevada produção e dispersão de sementes e os crescentes relatos de biótipos resistentes ao glyphosate, paraquat e outros herbicidas, faz-se necessário o uso de diferentes ferramentas de manejo. Assim, o objetivo deste estudo foi avaliar a eficácia de herbicidas com aplicação sequencial de glufosinate em pré-semeadura da soja, no controle de Conyza spp. com indicativo de resistência ao paraquat. O estudo foi realizado em campo nos municípios de Assis Chateaubriand e Palotina, estado do Paraná (PR), Brasil, na safra 2018/19. O delineamento experimental utilizado foi o de blocos casualizados, com quatro repetições. Os tratamentos foram compostos pela aplicação de glyphosate, 2,4-D, saflufenacil, glufosinate, saflufenacil/imazethapyr, diclosulam, paraquat/diuron, paraquat e imazethapyr/flumioxazin, em diferentes combinações em présemeadura da soja. Foram avaliados controle de Conyza spp., sintomas de injúria nas plantas de soja e variáveis relacionadas ao desempenho agronômico (altura de plantas e produtividade). Todos os tratamentos mostraram-se seletivos a soja. Visualizou-se maiores sintomas de injúria quando se tinha a presença do herbicida diclosulam, mas não resultou em danos ao desempenho agronomico da soja. De forma geral os niveis de controle foram altos para os tratamentos utilizados, em exceção para os tratamentos com paraquat na área que apresentava maior frequência de Conyza spp. com indicativo de resistência a este herbicida, e para o tratamento com imazethapyr/flumioxazin nas duas áreas. Estes resultados de controle enfatizam a importância do glufosinate neste sistema de manejo e demostram resultados promissores para saflufenacil/imazethapyr.

Palavras-chave: resistência a glyphosate, resistência a paraquat, inibidores da glutamina-sintetase, Glycine max L. Merr.

\section{INTRODUCTION}

Hairy fleabane (Conyza bonariensis), horseweed (Conyza canadensis) and Sumatran fleabane (Conyza sumatrensis) is among the main weeds found worldwide (TRAINER et al. 2005). Conyza spp. is an annual herbaceous plant, belonging to Asteraceae family, (LORENZI, 2014) with high seed production, reported in various agricultural environments, such as grain crops and in undisturbed 
areas (MOREIRA \& BRAGANÇA, 2011). The dispersion of Conyza spp. occurs exclusively by seeds present in the achene fruit. The number of seeds varies from 100 to 200 thousand per plant (DAUER et al., 2007).

In addition to the high seed production and dispersion, these three species have 105 reported herbicide-resistant biotypes (HEAP, 2020). For example, $C$. sumatrensis shows multiple resistance to glyphosate and chlorimuron (SANTOS et al., 2014). Recent studies showed there are biotypes of C. sumatrensis with resistance to paraquat (state of Paraná) (ZOBIOLE et al., 2019), or 2,4-D (state of Rio Grande do Sul) (QUEIROZ et al., 2020).

The use of herbicide combinations, rotation of sites of action, rotation of transgenic events, cover crops, crop rotations, and others are key in the management, and prevention of selection of herbicide resistant weed biotypes (BROSTER et al., 2019; MacLAREN et al., 2019; ROSARIO-LEBRON et al., 2019). In addition, the use of pre-emergence and burndown herbicides at tank-mixed before sowing soybeans for effective management of $C$. sumatrensis resistant to paraquat. Among the burndown herbicides can be highlighted the glufosinate (MONTGOMERY et al., 2017; ZOBIOLE et al., 2018). While, other studies highlighted the efficacy of herbicides with preemergent action in controlling Conyza spp. in soybeans. These herbicides include flumioxazin (ZIMMER et al., 2018), diclosulam (BRAZ et al., 2017), imazethapyr (HEDGES et al., 2019), among others.

Thus, in order to control C. sumatrensis, with recent cases of resistance to paraquat and 2,4-D, the use of alternative herbicides should be considered. Therefore, the aim of this study was to evaluate the efficacy of herbicides, with sequential application of glufosinate in soybean pre-sowing, atcontrol of Conyza spp. with indicative of resistance to paraquat.

\section{MATERIALS AND METHODS}

\section{Site description and experimental design}

The experiments were carried out in the field, in the 2018/19 season, at Assis Chateaubriand

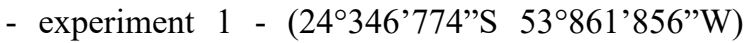
and Palotina - experiment 2 - $\left(24^{\circ} 20^{\prime} 44.54^{\prime \prime} \mathrm{S}\right.$ $\left.53^{\circ} 51^{\prime} 50.93^{\prime} \mathrm{W}\right)$, state of Paraná (PR), Brazil. The predominant climate in this region is $\mathrm{Cfa}$, a subtropical climate with warm summer, according to the Köppen classification (PEDRON et al., 2013) the weather conditions for the experimental period are illustrated in figures 1 and 2. For experiment

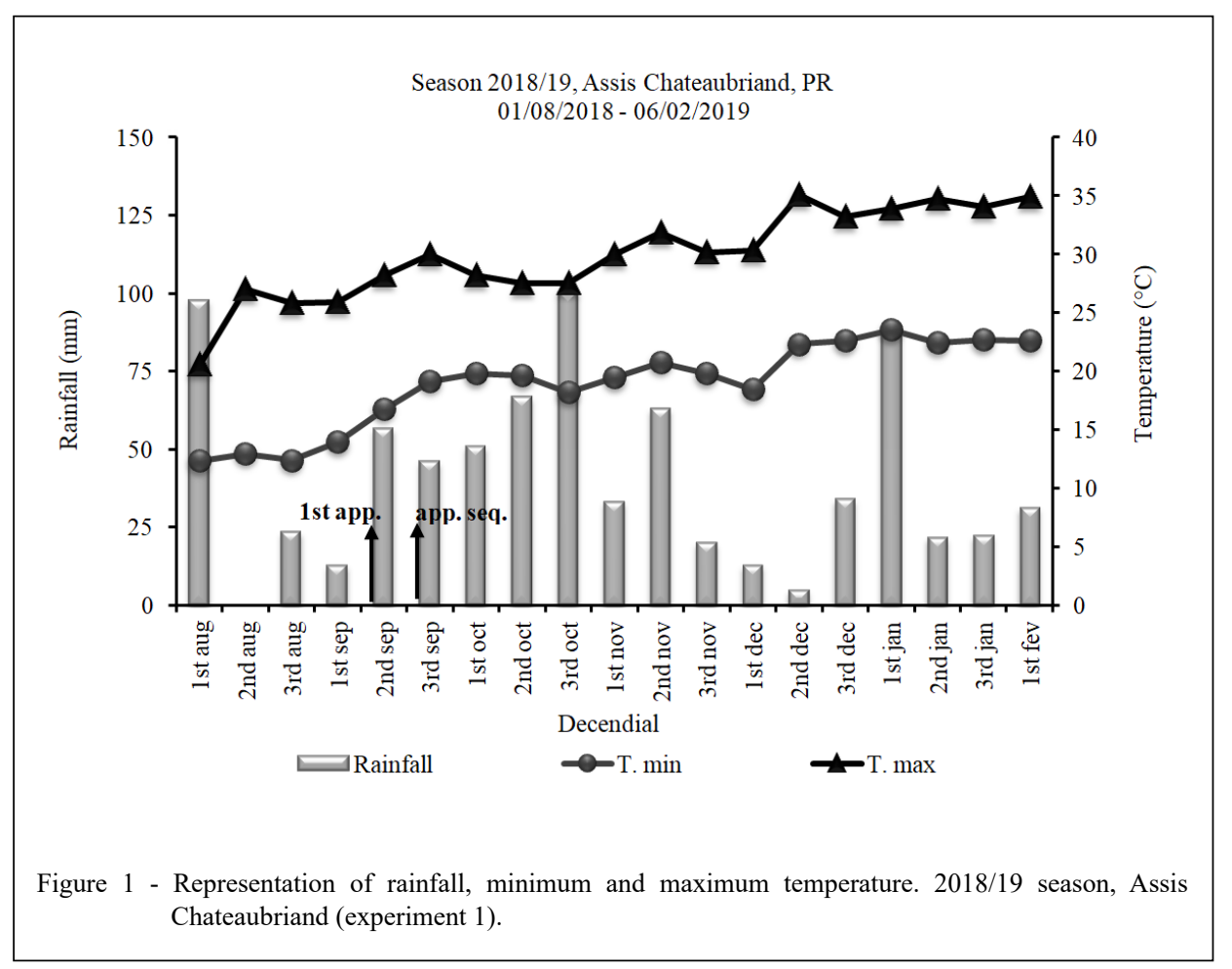

Ciência Rural, v.50, n.9, 2020. 
1 , the soil was classified as clay texture $(66.25 \%$ clay, $18.75 \%$ silt and $15 \%$ sand) with the following chemical characteristics in the $0-20 \mathrm{~cm}$ layer: $\mathrm{pH}$ $\left(\mathrm{CaCl}_{2}\right)$ of $4.8,1.55 \% \mathrm{OM}$ and $\mathrm{CEC}$ of $12.41 \mathrm{cmol}$ $\mathrm{dm}^{-3}$. For experiment 2, the soil was also classified as clay texture $(66.25 \%$ clay, $16.25 \%$ silt and $17.5 \%$ sand), with $\mathrm{pH}\left(\mathrm{CaCl}_{2}\right)$ of 5.2, 3.7\% $\mathrm{OM}$ and $\mathrm{CEC}$ of $14.64 \mathrm{cmol}_{\mathrm{c}} \mathrm{dm}^{-3}$.

Previously, the areas were cultivated with maize, and the experiments were infested with Conyza spp. with indicative of resistance to paraquat. For experiment 1 with a density of 13 plants $\mathrm{m}^{-2}(>$ $15 \mathrm{~cm})$ and 3 plants $\mathrm{m}^{-2}(<15 \mathrm{~cm})$, with about $35 \%$ population of plants with indicative of resistance to paraquat. For experiment 2, the infestation was 11 plants $\mathrm{m}^{-2}(>15 \mathrm{~cm})$ and 8 plants $\mathrm{m}^{-2}(<15 \mathrm{~cm})$, with about $5 \%$ population plants with indicative of resistance to paraquat. To determine the frequency of the plants with indicative of resistance to paraquat, 14 days before the experiment was installed, paraquat (Gramoxone ${ }^{\circledR} 200$ ) application at tracks was performed, at label rate $\left(400 \mathrm{~g}\right.$ a.i. ha $\left.{ }^{-1}\right)$. The number of uncontrolled plants ( $\leq 20 \%$ of control), with 6 to 10 leaves (4 to $8 \mathrm{~cm}$ height), was evaluated, compared to the track without application, before and after application. Seven days after the paraquat application, a second application was performed to determine the frequencies.

Soybean sowing occurred in no-tillage system, with $0.45 \mathrm{~cm}$ spacing between rows and 4 to $5 \mathrm{~cm}$ of sowing depth. The soybean cultivar BS 2606 IPRO (Basf S.A., São Paulo, SP, Brazil) was used for experiment 1 and Monsoy ${ }^{\circledR} 5947$ IPRO (Monsanto Co. Brazil, São Paulo, SP, Brazil) for experiment 2. The experiments were a randomized block design with four replications. The plots were composed of six soybean rows with 5 meters of length. Treatments for the control of Conyza spp. are described in table 1 . The dates of application, sowing and environmental conditions during applications are listed in table 2. Sequential application occurred on the same day for experiment 1 , while in experiment 2 one day before sowing.

All applications were performed with a pressurized $\mathrm{CO}_{2}$ backpack sprayer equipped with six AIXR 110.015 nozzles at a pressure of $2.5 \mathrm{kgf.cm}{ }^{-2}$ and a speed of $3.6 \mathrm{~km} \mathrm{~h}^{-1}$, providing an application volume of $150 \mathrm{~L} \mathrm{ha}^{-1}$.

\section{Evaluations}

The control of Conyza spp. was evaluated at soybean sowing and at 1, 3 and 5 weeks after

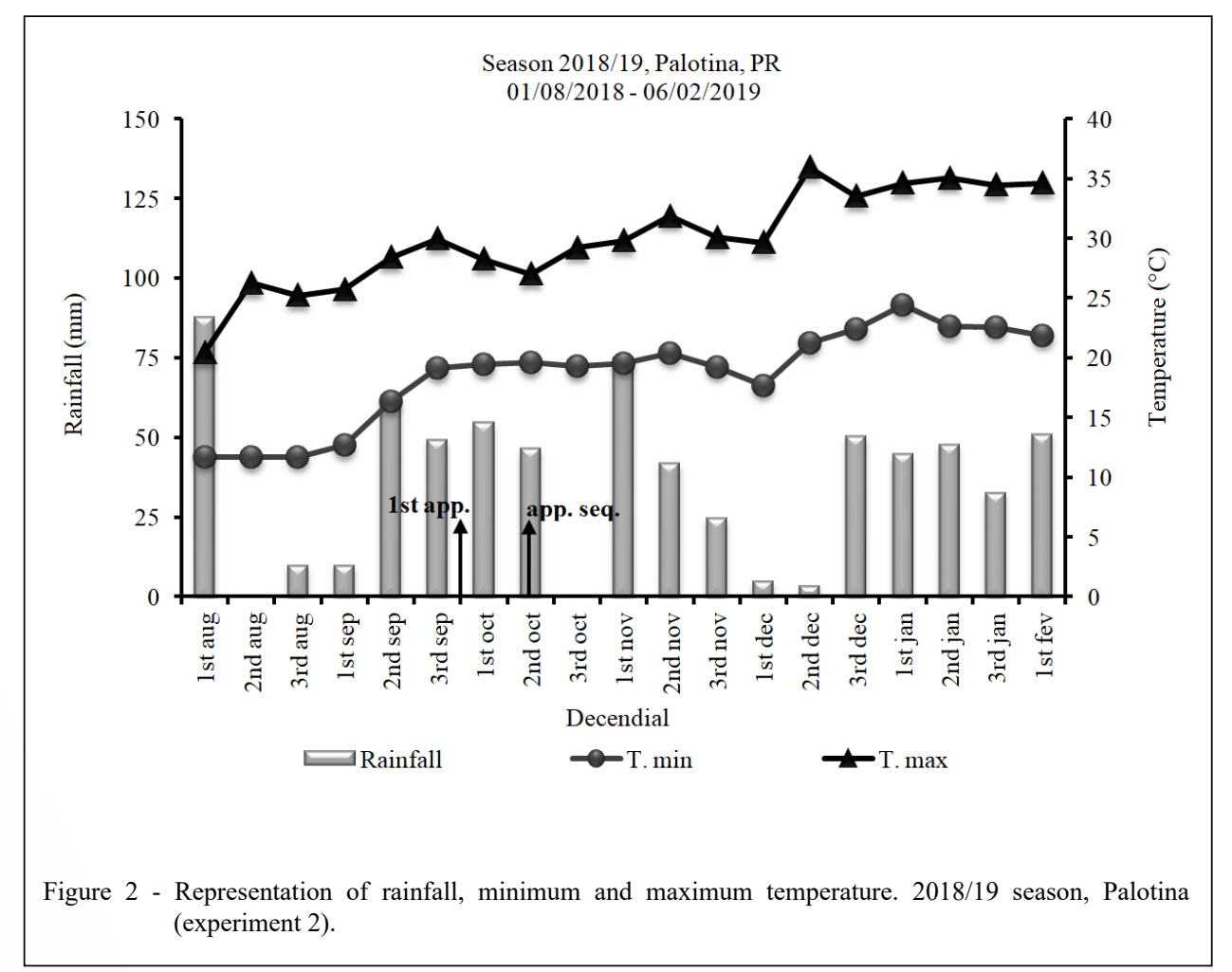

Ciência Rural, v.50, n.9, 2020. 
Table 1 - Treatments for the control of Conyza spp. 2018/19 season.

\begin{tabular}{|c|c|}
\hline Treatments $^{a}$ & Rates $^{b}$ \\
\hline weedy control (without application) & - \\
\hline glyphosate $+2,4-\mathrm{D}$ seq. glufosinate $^{1}$ & $1500+670$ seq. 400 \\
\hline 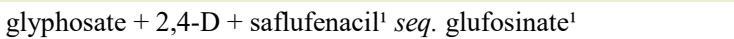 & $1500+670+35$ seq. 400 \\
\hline glyphosate + saflufenacil $^{1}$ seq. glufosinate $^{1}$ & $1500+35$ seq. 400 \\
\hline glufosinate + saflufenacil/imazethapyr ${ }^{1}$ seq. glufosinate $^{1}$ & $600+35.6 / 100.4$ seq. 400 \\
\hline glufosinate $+2,4-\mathrm{D}^{1}$ seq. glufosinate ${ }^{1}$ & $600+670$ seq. 400 \\
\hline paraquat/diuron ${ }^{2}$ seq. glufosinate ${ }^{1}$ & $400 / 200$ seq. 400 \\
\hline glufosinate + saflufenacil/imazethapyr ${ }^{1}$ seq. glufosinate $^{1}$ & $400+35.6 / 100.4$ seq. 400 \\
\hline glyphosate + glufosinate $^{1}$ seq. glufosinate $^{1}$ & $1500+400$ seq. 400 \\
\hline glyphosate + diclosulam seq. glufosinate ${ }^{1}$ & $1500+25.2$ gseq. 400 \\
\hline glyphosate + diclosulam + saflufenacil $^{1}$ seq. glufosinate ${ }^{1}$ & $1500+25.2 \mathrm{~g} \mathrm{seq.} 400$ \\
\hline glufosinate + saflufenacil/imazethapyr $+2,4-\mathrm{D}^{1}$ seq. glufosinate $^{1}$ & $600+35.6 / 100.4+670$ seq. 400 \\
\hline paraquat $^{2}$ seq. glufosinate $^{1}$ & 400 seq. 400 \\
\hline $2,4-\mathrm{D}+$ saflufenacil/imazethapyr $^{1}$ seq. glufosinate $^{1}$ & $670+35.6 / 100.4$ seq. 400 \\
\hline glyphosate + imazethapyr/flumioxazin ${ }^{1}$ seq. glufosinate $^{1}$ & $1500+100 / 50$ seq. 400 \\
\hline weed-free control (without application) & - \\
\hline
\end{tabular}

${ }^{a}$ Commercial products: Zapp ${ }^{\circledR}$ QI 620 (glyphosate), DMA ${ }^{\circledR} 806$ BR (2,4-D), Heat ${ }^{\circledR}$ (saflufenacil), Finale ${ }^{\circledR}$ (glufosinate), Optill ${ }^{\circledR}$ (saflufenacil/imazethapyr), Spider ${ }^{\circledR} 840$ WG (diclosulam), Gramocil ${ }^{\circledR}$ (paraquat/diuron), Gramoxone ${ }^{\circledR} 200$ (paraquat), Zethamaxx ${ }^{\circledR}$ (imazethapyr/flumioxazin).

${ }^{b}$ Rates at g a.e. ha ${ }^{-1}$, for glyphosate, 2,4-D and imazethapyr. Rates at g a.i. ha ${ }^{-1}$, for other herbicides. ${ }^{1}$ Adjuvant Mees ${ }^{\circledR}\left(500 \mathrm{~mL}\right.$ ha $\left.{ }^{-1}\right)$ use.

${ }^{2}$ Adjuvant $\operatorname{Agral}^{\circledR}\left(250 \mathrm{~mL} \mathrm{ha}^{-1}\right)$ use. seq.: sequential application.

sequential herbicide application (WAA). After the last control evaluation, all the plots of the treatments were weeded except the weedy control. At 2 and 5 weeks after sowing (WAS), crop injury in the soybean plants was evaluated. These evaluations were carried out through visual evaluation at each experimental unit ( 0 for no injuries, up to $100 \%$ for plant death), considering in this case, significantly visible symptoms in the plants, according to their development (VELINI et al.,1995).

Upon harvest, plant height and yield were evaluated. For height evaluation, plants were measured, from the soil surface to the last fully expanded trifoliate, with a wooden ruler, 10 plants evaluated per plot. For yield, the two central rows were harvested (four meters in length), the moisture was corrected to $13 \%$.

\section{Statistical analysis}

Analysis of variance and F-test $(\mathrm{P}<0.05)$ were applied according to PIMENTEL-GOMES \& GARCIA (2002). Treatment mean values were grouped by SCOTT \& KNOTT'S (1974) test $(\mathrm{P}<0.05)$. All analyses were performed using the

Table 2 - Dates and weather conditions during herbicide applications.

\begin{tabular}{lcccc}
\hline & Date & Wind $\left(\mathrm{km} \mathrm{h}^{-1}\right)$ & T. $\left({ }^{\circ} \mathrm{C}\right)$ & Relative humidity $(\%)$ \\
\hline Exp. 1 (1st application) & Sep 13, 2018 & 4.1 & 29.1 & 56.1 \\
Exp. 1 (sequential application) ${ }^{a}$ & Sep 23, 2018 & 6.5 & 29.6 & 62.7 \\
Exp. 2 (1st aplicação) & Sep 30, 2018 & 4.5 & 23.1 & 62.5 \\
Exp. 2 (sequential application) ${ }^{b}$ & Oct 14, 2018 & 2.8 & 29.2 & 66.3 \\
\hline
\end{tabular}

${ }^{a}$ Performed on the same day of sowing. ${ }^{b}$ Performed one day before sowing. 
statistical software Sisvar 5.6 (FERREIRA, 2011). For the weed control and crop injury variables, a significant effect was verified for source experiment $(P<0.05)$, then a separate analysis of each experiment was performed. For the variables height and yield of soybean, no significant effect was verified for source experiment $(\mathrm{P}>0.05)$, thus, the experiments were combined for analysis.

\section{RESULTS}

Table 3 presents Conyza spp. control and soybean injury scores for experiment 1 . Injury was verified for the application of glyphosate + diclosulam + saflufenacil and glyphosate + diclosulam, with percentages higher than all other treatments. Injuries were $4.3 \%$ and $3.5 \%$ for these two treatments, at 5 WAS. For the other treatments, no crop injury was observed at most $0.3 \%$, without differences from each other even in relation to weedy or weed-free controls.

In the sowing evaluation, the treatments glyphosate + saflufenacil $(92 \%)$, glufosinate + saflufenacil/imazethapyr $\quad(93 \%)$, glyphosate + diclosulam + saflufenacil $(96 \%)$ provided the highest controls of Conyza spp., superior to all other treatments, equal to the weed-free control with $100 \%$ control. The control evaluation performed at sowing occurred 10 days after the first application, these percentages reflected the control of the first application only. The following evaluations reflected control of the first application + sequential application of glufosinate.

At 1 WAA, $69 \%$ of control was observed for paraquat and $76 \%$ for paraquat/diuron, these two treatments remained among the worst for Conyz $a$ spp. control until 5 WAA evaluation, with controls of $57 \%$ and $53 \%$, respectively. This is due to the frequency of $35 \%$ of Conyza spp. with indicative of resistance to paraquat, so the first application was inefficient and only the second application could not do all the control. For other treatments, from 1 to 5 WAA, a control of at least $70 \%$ was verified. Highlighting glufosinate $+2,4-\mathrm{D}(93 \%)$, glyphosate + diclosulam + saflufenacil (96\%) and glufosinate + saflufenacil/ imazethapyr + 2,4-D (93\%) at 5 WAA, superior to the other treatments, in the same control level observed for the weed-free control $(100 \%)$.

Table 4 lists Conyza spp. control and soybean injury for experiment 2 . As in experiment

Table 3 - Conyza spp. control (\%) and soybean injury (\$) after herbicide application. 2018/19 season, Assis Chateaubriand (experiment 1).

\begin{tabular}{|c|c|c|c|c|c|c|}
\hline & Sow & 1WAA & 3WAA & 5WAA & 2WAS & 5WAS \\
\hline Weedy control (without application) & $0 \mathrm{e}$ & $0 \mathrm{~g}$ & $0 \mathrm{e}$ & $0 \mathrm{e}$ & $0.0 \mathrm{a}$ & $0.0 \mathrm{a}$ \\
\hline gly $+2,4-\mathrm{D}$ seq. glu & $44 \mathrm{c}$ & $82 \mathrm{~d}$ & $82 \mathrm{c}$ & $83 \mathrm{~b}$ & $2.5 \mathrm{c}$ & $0.0 \mathrm{a}$ \\
\hline gly $+2,4-\mathrm{D}+$ saflufenacil seq. glu & $87 \mathrm{~b}$ & $92 \mathrm{~b}$ & $90 \mathrm{~b}$ & $89 \mathrm{~b}$ & $2.5 \mathrm{c}$ & $0.3 \mathrm{a}$ \\
\hline gly + saflufenacil seq. glu & $91 \mathrm{a}$ & $93 \mathrm{~b}$ & $91 \mathrm{~b}$ & $89 \mathrm{~b}$ & $0.8 \mathrm{a}$ & $0.0 \mathrm{a}$ \\
\hline glu + saflufenacil/imazethapyr seq. glu & 93 a & $91 \mathrm{~b}$ & $89 \mathrm{~b}$ & $88 \mathrm{~b}$ & $1.8 \mathrm{~b}$ & $0.0 \mathrm{a}$ \\
\hline glu + 2,4-D seq. glu & $88 \mathrm{~b}$ & $93 \mathrm{~b}$ & $92 \mathrm{a}$ & $93 \mathrm{a}$ & $1.5 \mathrm{~b}$ & $0.0 \mathrm{a}$ \\
\hline paraquat/diuron seq. glu & $40 \mathrm{c}$ & $76 \mathrm{e}$ & $67 \mathrm{~d}$ & $53 \mathrm{~d}$ & $0.0 \mathrm{a}$ & $0.0 \mathrm{a}$ \\
\hline glu + saflufenacil/imazethapyr seq. glu & $89 \mathrm{~b}$ & $90 \mathrm{~b}$ & $85 \mathrm{~b}$ & $86 \mathrm{~b}$ & $0.5 \mathrm{a}$ & $0.0 \mathrm{a}$ \\
\hline gly + glu seq. glu & $84 \mathrm{~b}$ & $87 \mathrm{c}$ & $80 \mathrm{c}$ & $80 \mathrm{~b}$ & $0.0 \mathrm{a}$ & $0.0 \mathrm{a}$ \\
\hline gly + diclosulam seq. glu & $28 \mathrm{~d}$ & $87 \mathrm{c}$ & $88 \mathrm{~b}$ & $85 \mathrm{~b}$ & $3.3 \mathrm{~d}$ & $3.5 \mathrm{~b}$ \\
\hline gly + diclosulam + saflufenacil seq. glu & $96 \mathrm{a}$ & $98 \mathrm{a}$ & $95 \mathrm{a}$ & $96 \mathrm{a}$ & $3.5 \mathrm{~d}$ & $4.3 \mathrm{~b}$ \\
\hline glu + saflufenacil/imazethapyr $+2,4-\mathrm{D}$ seq. glu & $89 \mathrm{~b}$ & $95 \mathrm{a}$ & $94 \mathrm{a}$ & 93 a & $1.0 \mathrm{a}$ & $0.0 \mathrm{a}$ \\
\hline paraquat seq. glu & $23 \mathrm{~d}$ & $69 \mathrm{f}$ & $68 \mathrm{~d}$ & $57 \mathrm{c}$ & $0.0 \mathrm{a}$ & $0.0 \mathrm{a}$ \\
\hline 2,4-D + saflufenacil/imazethapyr seq. glu & $83 \mathrm{~b}$ & $94 \mathrm{~b}$ & $90 \mathrm{~b}$ & $85 \mathrm{~b}$ & $1.5 \mathrm{~b}$ & $0.0 \mathrm{a}$ \\
\hline gly + imazethapyr/flumioxazin seq. glu & $39 \mathrm{c}$ & $80 \mathrm{~d}$ & $78 \mathrm{c}$ & $70 \mathrm{c}$ & $1.5 \mathrm{~b}$ & $0.0 \mathrm{a}$ \\
\hline weed-free control (without application) & $100 \mathrm{a}$ & $100 \mathrm{a}$ & $100 \mathrm{a}$ & $100 \mathrm{a}$ & $0.0 \mathrm{a}$ & $0.0 \mathrm{a}$ \\
\hline Mean & 67.1 & 82.8 & 89.7 & 77.8 & 1.3 & 0.5 \\
\hline CV (\%) & 8.2 & 4.4 & 2.6 & 7.8 & 13.1 & 11.7 \\
\hline $\mathrm{F}$ & $*$ & $*$ & $*$ & $*$ & $*$ & $*$ \\
\hline
\end{tabular}

Sow: sowing. WAA: weeks after sequential application. WAS: weeks after sowing. gly: glyphosate. glu: glufosinate. seq.: sequential application. 
1 , injury symptom was registered for the application of glyphosate + diclosulam + saflufenacil (5\%) and glyphosate + diclosulam $(6.3 \%)$ at 5 WAS. For experiment 2, none of the treatments in the sowing evaluation were at the same level as the control of $100 \%$ weed-free control. The best percentages were observed for glyphosate + saflufenacil (84\%), glufosinate + saflufenacil/imazethapyr $(83 \%)$, glyphosate + diclosulam + saflufenacil $(89 \%)$ and glufosinate + saflufenacil/imazethapyr $+2,4-\mathrm{D}(84 \%)$, all of these were inferior only to the weed-free control.

As in experiment 1, also for experiment 2, the percentages in the sowing evaluation reflect the control of the first application only, with the effect of sequential application (glufosinate) observed in the following evaluations. From 1 to 5 WAA, a control of at least $77.5 \%$ was observed for the application of glyphosate + imazethapyr/flumioxazin, while for the application of glyphosate + diclosulam, $80 \%$ control. Other treatments provided excellent control ( $\geq 93 \%$ ). In this area, the frequency of Conyza spp. with indicative of resistance to paraquat was very low $(5 \%)$.

For agronomic performance, differences in height and yield were verified, with reductions in weedy control (without application), without differences between the other treatments. Results indicated the selectivity of herbicide treatments (Table 5).

\section{DISCUSSION}

Noteworthy is the control provided by the treatments with glufosinate. Glufosinate $+2,4-\mathrm{D}$ and glufosinate + saflufenacil/imazethapyr $+2,4-\mathrm{D}$ treatments are among the most effective in controlling Conyza spp. in both experiments. It is emphasized that glufosinate was used in the sequential application, that is, without any application of paraquat and glyphosate, but nonetheless effective in the control. Glyphosate and paraquat are a very important herbicide for weed management; however, with the increasing cases of resistant weeds, other herbicides are important when considering the management of these resistant weeds, as well as preventing the selection of new resistant biotypes.

In recent years, reports of Conyza spp. resistant to herbicides increased in Brazil (HEAP, 2020). C. sumatrensis showed multiple resistance to glyphosate and chlorimuron (SANTOS et al.,

Table 4 - Conyza spp. control and soybean injury after herbicide application. 2018/19 season, Palotina (experiment 2).

\begin{tabular}{|c|c|c|c|c|c|c|}
\hline \multirow[t]{2}{*}{ Treatments } & \multicolumn{4}{|c|}{ - } & \multicolumn{2}{|c|}{---Crop injury $(\%)--$} \\
\hline & Sow & 1WAA & 3WAA & 5WAA & 2WAS & 5WAS \\
\hline weedy control (without application) & $0 \mathrm{i}$ & $0 \mathrm{f}$ & $0 \mathrm{~d}$ & $0 \mathrm{~d}$ & $0.0 \mathrm{a}$ & $0.0 \mathrm{a}$ \\
\hline gly $+2,4-\mathrm{D}$ seq. glu & $47 \mathrm{f}$ & $85 \mathrm{~d}$ & $91 \mathrm{~b}$ & $93 \mathrm{~b}$ & $0.5 \mathrm{~b}$ & $0.8 \mathrm{~b}$ \\
\hline gly $+2,4-\mathrm{D}+$ saflufenacil seq. glu & $81 \mathrm{c}$ & $98 \mathrm{a}$ & 99 a & $98 \mathrm{a}$ & $0.8 \mathrm{~b}$ & $1.5 \mathrm{~b}$ \\
\hline gly + saflufenacil seq. glu & $84 \mathrm{~b}$ & $97 \mathrm{a}$ & $99 \mathrm{a}$ & $99 \mathrm{a}$ & $0.0 \mathrm{a}$ & $0.0 \mathrm{a}$ \\
\hline glu + saflufenacil/imazethapyr seq. glu & $83 \mathrm{~b}$ & $94 \mathrm{a}$ & 98 a & 99 a & $0.5 \mathrm{~b}$ & $1.0 \mathrm{~b}$ \\
\hline glu $+2,4-D$ seq. glu & $72 \mathrm{~d}$ & $95 \mathrm{a}$ & $98 \mathrm{a}$ & $98 \mathrm{a}$ & $0.5 \mathrm{~b}$ & $0.5 \mathrm{~b}$ \\
\hline paraquat/diuron seq. glu & $60 \mathrm{e}$ & $94 \mathrm{a}$ & $98 \mathrm{a}$ & $95 \mathrm{~b}$ & $0.0 \mathrm{a}$ & $0.0 \mathrm{a}$ \\
\hline glu + saflufenacil/imazethapyr seq. glu & $79 \mathrm{c}$ & $97 \mathrm{a}$ & $99 \mathrm{a}$ & $99 \mathrm{a}$ & $0.5 \mathrm{~b}$ & $0.8 \mathrm{~b}$ \\
\hline gly + glu seq. glu & $80 \mathrm{c}$ & $96 \mathrm{a}$ & $99 \mathrm{a}$ & 99 a & $0.0 \mathrm{a}$ & $0.0 \mathrm{a}$ \\
\hline gly + diclosulam seq. glu & $18 \mathrm{~h}$ & $84 \mathrm{~d}$ & $83 \mathrm{c}$ & $80 \mathrm{c}$ & $2.3 \mathrm{c}$ & $6.3 \mathrm{~d}$ \\
\hline gly + diclosulam + saflufenacil seq. glu & $89 \mathrm{~b}$ & $97 \mathrm{a}$ & $99 \mathrm{a}$ & $99 \mathrm{a}$ & $2.3 \mathrm{c}$ & $5.0 \mathrm{c}$ \\
\hline glu + saflufenacil/imazethapyr $+2,4-\mathrm{D}$ seq. glu & $84 \mathrm{~b}$ & $95 \mathrm{~b}$ & 99 a & $99 \mathrm{a}$ & $0.8 \mathrm{~b}$ & $1.3 \mathrm{~b}$ \\
\hline paraquat seq. glu & $51 \mathrm{f}$ & $89 \mathrm{c}$ & 97 a & $93 \mathrm{~b}$ & $0.0 \mathrm{a}$ & $0.0 \mathrm{a}$ \\
\hline 2,4-D + saflufenacil/imazethapyr seq. glu & $79 \mathrm{c}$ & $95 \mathrm{~b}$ & $97 \mathrm{a}$ & $98 \mathrm{a}$ & $0.8 \mathrm{~b}$ & $1.5 \mathrm{~b}$ \\
\hline gly + imazethapyr/flumioxazin seq. glu & $34 \mathrm{~g}$ & $80 \mathrm{e}$ & $82 \mathrm{c}$ & $78 \mathrm{c}$ & $0.5 \mathrm{~b}$ & $1.0 \mathrm{~b}$ \\
\hline Weed-free control (without application) & $100 \mathrm{a}$ & $100 \mathrm{a}$ & $100 \mathrm{a}$ & $100 \mathrm{a}$ & $0.0 \mathrm{a}$ & $0.0 \mathrm{a}$ \\
\hline Mean & 64,9 & 87.1 & 89.7 & 89.1 & 0.6 & 1.2 \\
\hline $\mathrm{CV}(\%)$ & 6,6 & 2.5 & 2.6 & 3.2 & 14.3 & 18.6 \\
\hline $\mathrm{F}$ & $*$ & $*$ & $*$ & $*$ & $*$ & $*$ \\
\hline
\end{tabular}

Sow: sowing. WAA: weeks after sequential application. WAS: weeks after sowing. gly: glyphosate. glu: glufosinate. seq.: sequential application.

*Means followed by the same letter in the column do not differ from each other by SCOTT \& KNOTT's (1974) test (P<0.05). 
Table 5 - Soybean height and yield after herbicide application. 2018/19 season, Assis Chateaubriand and Palotina (means of experiments).

\begin{tabular}{|c|c|c|}
\hline Treatments & Heigth (cm) & Yield $\left(\mathrm{kg} \mathrm{ha}^{-1}\right)$ \\
\hline Weedy control (without application) & $55.2 \mathrm{~b}$ & $433 \mathrm{~b}$ \\
\hline gly $+2,4-\mathrm{D}$ seq. glu & $65.4 \mathrm{a}$ & $2,585 \mathrm{a}$ \\
\hline gly $+2,4-\mathrm{D}+$ saflufenacil seq. glu & $67.5 \mathrm{a}$ & $2,488 \mathrm{a}$ \\
\hline gly + saflufenacil seq. glu & $68.6 \mathrm{a}$ & $2,560 \mathrm{a}$ \\
\hline glu + saflufenacil/imazethapyr seq. glu & $67.2 \mathrm{a}$ & $2,646 \mathrm{a}$ \\
\hline glu $+2,4-D$ seq. glu & $67.2 \mathrm{a}$ & $2,651 \mathrm{a}$ \\
\hline paraquat/diuron seq. glu & $66.2 \mathrm{a}$ & $2,391 \mathrm{a}$ \\
\hline glu + saflufenacil/imazethapyr seq. glu & $65.5 \mathrm{a}$ & $2,593 \mathrm{a}$ \\
\hline gly + glu seq. glu & $68.6 \mathrm{a}$ & $2,643 \mathrm{a}$ \\
\hline gly + diclosulam seq. glu & $67.0 \mathrm{a}$ & $2,487 \mathrm{a}$ \\
\hline gly + diclosulam + saflufenacil seq. glu & $67.0 \mathrm{a}$ & 2,649 a \\
\hline glu + saflufenacil/imazethapyr $+2,4-\mathrm{D}$ seq. glu & $67.9 \mathrm{a}$ & $2,614 \mathrm{a}$ \\
\hline paraquat seq. glu & $68.9 \mathrm{a}$ & $2,399 \mathrm{a}$ \\
\hline 2,4-D + saflufenacil/imazethapyr seq. glu & $66.2 \mathrm{a}$ & 2,673 a \\
\hline gly + imazethapyr/flumioxazin seq. glu & $67.4 \mathrm{a}$ & $2,328 \mathrm{a}$ \\
\hline weed-free control (without application) & $68.3 \mathrm{a}$ & $2,612 \mathrm{a}$ \\
\hline Mean & 66.5 & 2,422 \\
\hline CV $(\%)$ & 5.1 & 11.1 \\
\hline $\mathrm{F}$ & ${ }^{*}$ & * \\
\hline
\end{tabular}

"Means followed by the same letter in the column do not differ from each other by SCOTT\& KNOTT's $(1974)$ test $(\mathrm{P}<0.05)$.

2014). Recent studies showed that in the western region of the state of Paraná, there are biotypes of C. sumatrensis with simple resistance to paraquat (ZOBIOLE et al. 2019) and multiple resistance to paraquat, glyphosate and chlorimuron (HEAP, 2020). In this way, glufosinate combined with 2,4-D and saflufenacil/imazethapyr stands out, as observed in this study.

Glufosinate (400 g a.i. ha $\left.{ }^{-1}\right)$ was effective in controlling glyphosate-resistant $C$. bonariensis for pre-flowering application in combination with MSMA, bromacil/diuron or metsulfuron, with scores higher than $90 \%$ at 28 DAA (MOREIRA et al., 2010). Other studies have also reported the efficacy of glufosinate in different chemical management programs in controlling Conyza spp. (MONTGOMERY et al., 2017; TAHMASEBI et al., 2018; ZOBIOLE et al., 2018). In addition to these results, other studies reported the efficacy of glufosinate in different management programs in controlling other weeds, for example Amaranthus palmeri (MANUCHEHRI et al., 2017), Sorghum halepense (LANDRY et al., 2016), Digitaria sanguinalis (AULAKH \& JHALA, 2015) and Digitaria insularis (MELO et al., 2012; GEMELLI et al., 2013).
Another highlight is the efficacy of saflufenacil/imazethapyr in combination with glufosinate and/or 2,4-D, with final controls of at least $86 \%$ in experiment 1 and $98.5 \%$ in experiment 2 . PIASECKI et al. (2017) found 96\% control of Conyza spp. at 35 DAA for application of glyphosate $(1,080$ g a.e. ha $\left.{ }^{-1}\right)+$ chlorimuron $\left(25\right.$ g a.i. ha $\left.{ }^{-1}\right)+2,4-D(670$ g a.e. ha $\left.{ }^{-1}\right)+$ saflufenacil $\left(50\right.$ g a.e. ha $\left.{ }^{-1}\right)$. BYKER et al. (2013), DALAZEN et al. (2015) and CESCO et al. (2019) also observed the efficacy of glyphosate + saflufenacil in controlling Conyza spp. All these studies demonstrated the efficacy of saflufenacil in combination with glyphosate or glufosinate in controlling Conyza spp.

It is essential the adoption of different measures in the management of Conyza spp. in integrated weed management, herbicide rotation and combination of different sites of action for controlling herbicide-resistant weeds, and preventing the selection of resistant biotypes. On the need for rotation of herbicides with different sites of action, new transgenics traits that provide tolerance to other herbicides such as glufosinate, imidazolinones, sulfonylureas, auxin mimics, among others may be useful in the prevention and control of herbicide- 
resistant weeds (GREEN, 2018; KNISS, 2018). In this context, the use of glufosinate and saflufenacil/ imazethapyr was promising to control C. sumatrensis, resistant to paraquat, in the present study.

All treatments were selective for soybean, which showed injury in the presence of diclosulam, but this did not compromise soybean agronomic performance. In general, control levels were high for the treatments tested, except for paraquat treatments in the area with the highest frequency of Conyza spp. with indicative of resistant to this herbicide, and for imazethapyr/flumioxazin treatment in both areas. These results emphasized the importance of glufosinate, and showed promising results for saflufenacil/imazethapyr, for management of Conyza spp. with resistant to paraquat, at pre-sowing soybean.

\section{DECLARATION OF CONFLICT OF} INTERESTS

The authors declare no conflict of interest. The founding sponsors had no role in the design of the study; in the collection, analyses, or interpretation of data; in the writing of the manuscript, and in the decision to publish the results.

\section{AUTHORS' CONTRIBUTIONS}

The authors contributed equally to the manuscript.

\section{REFERENCES}

AULAKH, J. S.; JHALA, A. J. Comparison of glufosinate-based herbicide programs for broad-spectrum weed control in glufosinateresistant soybean. Weed Technology, v.29, n.3, p.419-430, 2015. Available from: <https://doi.org/10.1614/WT-D-15-00014.1>. Accessed: Oct. 15, 2019. doi: 10.1614/WT-D-15-00014.1.

BRAZ, G. B. P. et al. Sumatran fleabane (Conyza sumatrensis) control in no-tillage soybean with diclosulam plus halauxifenmethyl. Weed Technology, v.31, n.2, p.184-192, 2017. Available from: <https://doi.org/10.1017/wet.2016.28>. Accessed: Mar. 25, 2020. doi: 10.1017/wet.2016.28.

BROSTER, J. C. et al. A quarter of a century of monitoring herbicide resistance in Lolium rigidum in Australia. Crop and Pasture Science, v.70, n.3, p.283-293, 2019. Available from: $<$ https://doi.org/10.1071/CP18584>. Accessed: Oct. 12, 2019. doi: $10.1071 / \mathrm{CP} 18584$.

BYKER, H. P. et al. Control of glyphosate-resistant Canada fleabane [Conyza canadensis (L.) Cronq.] with preplant herbicide tankmixes in soybean [Glycine $\max (\mathrm{L})$. Merr.]. Canadian Journal of Plant Science, v.93, n.4, p.659-667, 2013. Available from: $<$ https://doi.org/10.4141/cjps2012-320>. Accessed: Oct. 30, 2019. doi: $10.4141 /$ cjps2012-320.

CESCO, V. J. S. et al. Management of resistant Conyza spp. during soybean pre-sowing.Planta Daninha, v.37, e019181064,
2019. Available from: <http://dx.doi.org/10.1590/s010083582019370100039>. Accessed: Oct. 30, 2019. doi: 10.1590/ s0100-83582019370100039.

DALAZEN, G. et al. Synergism of the glyphosate and saflufenacil combination for controlling hairy fleabane. Pesquisa Agropecuária Tropical, v.45, n.2, p.249-256, 2015. Available from: <http://dx.doi. org/10.1590/1983-40632015v4533708>. Accessed: Oct. 30, 2019. doi: 10.1590/1983-40632015v4533708.

DAUER, J. T. et al. Temporal and spatial dynamics of longdistance Conyza canadensis seed dispersal. Journal of Applied Ecology, v.44, n.1, p.105-114, 2007.Available from: $<$ https://doi.or g/10.1111/j.1365-2664.2006.01256.x>. Accessed: Nov. 04, 2019. doi: $10.1111 / \mathrm{j} .1365-2664.2006 .01256 . x$.

FERREIRA, D. F. Sisvar: a computer statistical analysis system. Ciência e Agrotecnologia, v.35, n.6, p.1039-1042,2011. Available from: <http:// dx.doi.org/10.1590/S1413-70542011000600001>. Accessed: Mar. 08, 2019. doi: 10.1590/S1413-70542011000600001.

GEMELLI, A. et al. Estratégias para o controle de capimamargoso (Digitaria insularis) resistente ao glyphosate na cultura milho safrinha. Revista Brasileira de Herbicidas, v.12, n.2, p.162-170, 2013. Available from: <https://doi. org/10.7824/rbh.v12i2.201>. Accessed: Oct. 08, 2019. doi: 10.7824/rbh.v12i2.201.

GREEN, J. M. The rise and future of glyphosate and glyphosateresistant crops. Pest Management Science, v.74, n.5, p.10351039, 2018. Available from: <https://doi.org/10.1002/ps.4462>. Accessed: Oct. 30, 2019. doi: 10.1002/ps.4462.

HEAP, I. M. International survey of herbicide resistant weeds. 2020. Available from: $<$ http://www.weedscience.org $>$. Accessed: Apr. 07, 2020.

HEDGES, B. K. N. et al. Control of glyphosate-resistant Canada fleabane in Ontario with multiple effective modes-of-action in glyphosate/dicamba-resistant soybean. Canadian Journal of Plant Science, v.99, n.1, p.78-83, 2019. Available from: $<$ https:// doi.org/10.1139/cjps-2018-0067>. Accessed: Oct. 30, 2019. doi: $10.1139 /$ cjps-2018-0067.

KNISS, A. R. Genetically engineered herbicide-resistant crops and herbicide-resistant weed evolution in the United States. Weed Science, v.66, n.2, p.260-273, 2018. Available from: $<$ https://doi. org/10.1017/wsc.2017.70>. Accessed: Oct. 30, 2019. doi: 10.1017/ wsc. 2017.70 .

LANDRY, R. L. et al. Glufosinate rate and timing for control of glyphosate-resistant rhizomatous Johnsongrass (Sorghum halepense) in glufosinate-resistant soybean. International Journal of Agronomy, v.2016, 8040235, 2016. Available from: $<$ http://dx.doi.org/10.1155/2016/8040235>. Accessed: Oct. 30, 2019. doi: $10.1155 / 2016 / 8040235$.

LORENZI, H. Manual de identificação e controle de plantas daninhas: plantio direto e convencional. 7 ed. Nova Odessa: Plantarum, 2014.

MacLAREN, C. et al. Cover crop biomass production is more important than diversity for weed suppression. Crop Science, v.59, n.2, p.733-748, 2019. Available from: <https://doi.org/10.2135/ cropsci2018.05.0329>. Accessed: Oct. 30, 2019. doi: 10.2135/ cropsci2018.05.0329. 
MANUCHEHRI, M. R. et al. Enlist ${ }^{\mathrm{TM}}$ weed control systems for palmer amaranth (Amaranthus palmeri) management in Texas high plains cotton. Weed Technology, v.31, n.6, p.793-798,2017. Available from: $<$ https://doi.org/10.1017/wet.2017.55>. Accessed: Oct. 30, 2019. doi: 10.1017/wet.2017.55.

MELO, M. S. C. et al. Chemical control alternatives for sourgrass (Digitaria insularis) resistant to glyphosate. Revista Brasileira de Herbicidas, v.11, n.2, p.195-203, 2012. Available from: <https:// doi.org/10.7824/rbh.v11i2.145>. Accessed: Oct. 30, 2019. doi: 10.7824/rbh.v11i2.145.

MONTGOMERY, G. B. et al. Effect of time of day of application of 2,4-D, dicamba, glufosinate, paraquat, and saflufenacil on horseweed (Conyza canadensis) control. Weed Technology, v.31, n.4, p.550-556, 2017. Available from: <https://doi. org/10.1017/wet.2017.34>. Accessed: Oct. 30, 2019. doi: $10.1017 /$ wet.2017.34.

MOREIRA, H. J. C.; BRAGANÇA, H. N. P. Manual de identificação de plantas infestantes. Campinas: FMC Agricultural Products, 2011.

MOREIRA, M. S. et al. Alternative herbicides to control glyphosateresistant biotypes of Conyza bonariensis and C. canadensis. Planta Daninha, v.28, n.1, p.167-175, 2010. Available from: <http:// dx.doi.org/10.1590/S0100-83582010000100020>. Accessed: Oct. 30, 2019. doi: 10.1590/S0100-83582010000100020.

PEDRON, I. T. et al. Behavior of the Palotina/PR climate from 1973 to 2010. Scientia Agraria Paranaensis, v.12, p.411-419, 2013. Available from: <http://dx.doi.org/10.18188/sap.v12i0.9570>. Accessed: Mar. 25, 2020. doi: 10.18188/sap.v12i0.9570.

PIASECKI, C. et al. Technical effectiveness and economic return of the glyphosate-resistant hairy fleabane management in soybean pre-emergence. Revista Brasileira de Herbicidas, v.16, n.1, p.20-29, 2017. Available from: <https://doi. org/10.7824/rbh.v16i1.510>. Accessed: Oct. 20, 2019. doi: 10.7824/rbh.v16i1.510.

PIMENTEL-GOMES, F.; GARCIA, C.H. Estatística aplicada a experimentos agronômicos e florestais: exposição com exemplos e orientações para uso de aplicativos. Piracicaba: Fealq, 2002.

QUEIROZ, A. R. S. et al. Rapid necrosis: a novel plant resistance mechanism to 2,4-D. Weed Science, v.68, n.1, p.6-18, 2020. Available from: $<$ https://doi.org/10.1017/wsc.2019.65>. Accessed: Mar. 25, 2020. doi: 10.1017/wsc.2019.65.
ROSARIO-LEBRON, A. et al. Can winter cover crop termination practices impact weed suppression, soil moisture, and yield in no-till soybean [Glycine max (L.) Merr.]? Crop Protection, v.116, p.132-141, 2019. Available from: $<$ https://doi.org/10.1016/j.cropro.2018.10.020>. Accessed: Oct. 20, 2019. doi: 10.1016/j.cropro.2018.10.020.

SANTOS, G. et al.Multiple resistance of Conyzasumatrensis to chlorimuron-ethyl and to glyphosate. Planta Daninha, v.32, n.2, p.409-416, 2014. Available from: <http://dx.doi.org/10.1590/ S0100-83582014000200019>. Accessed: Oct. 20, 2019. doi: $10.1590 / \mathrm{S} 0100-83582014000200019$.

SCOTT, A. J.; KNOTT, M. A cluster analysis method for grouping means in the analysis of variance. Biometrics, v.30, p.507512, 1974. Available from: <https://doi.org/10.2307/2529204> Accessed: Oct. 20, 2019. doi: 10.2307/2529204.

TAHMASEBI, B. K. et al. Effectiveness of alternative herbicides on three Conyza species from Europe with and without glyphosate resistance. Crop Protection, v.112, p.350-355, 2018. Available from: <https://doi.org/10.1016/j.cropro.2018.06.021>. Accessed: Oct. 20, 2019. doi: 10.1016/j.cropro.2018.06.021.

TRAINER, G. D. et al. Response of horseweed biotypes to foliar applications of cloransulam-methyl and glyphosate. Weed Technology, v.19, n.2, p.231-236, 2005. Available from: <https:// doi.org/10.1614/WT-04-127R3>. Accessed: Oct. 20, 2019. doi: 10.1614/WT-04-127R3

VELINI, D. E. et al. Procedimentos para instalação, avaliação e análise de experimentos com herbicidas. Londrina: SBCPD, 1995.

ZIMMER, M., B. G et al. Herbicide programs utilizing halauxifenmethyl for glyphosate-resistant horseweed (Conyza canadensis) control in soybean. Weed Technology, v.32, p.659-664, 2018 Available from: $<$ https://doi.org/10.1017/wet.2018.60>. Accessed: Mar. 25, 2020. doi: 10.1017/wet.2018.60.

ZOBIOLE, L. H. S. et al. Management programs to control Conyza spp. in pre-soybean sowing applications. Planta Daninha, v.36, e018175883, 2018. Available from: < http://dx.doi.org/10.1590/ s0100-83582018360100076>. Accessed: Oct. 30, 2019. doi: $10.1590 / \mathrm{s} 0100-83582018360100076$.

ZOBIOLE, L. H. S. et al. Paraquat resistance of Sumatran fleabane (Conyza sumatrensis). Planta Daninha, v.37, e019183264, 2019. Available from: <http://dx.doi.org/10.1590/ s0100-83582019370100018>. Accessed: Oct. 30, 2019. doi: $10.1590 / \mathrm{s} 0100-83582019370100018$. 